\title{
EL HORROR FANTÁSTICO Y EL MIEDO \\ EN LOS MUERTOS, LAS MUERTAS Y OTRAS FANTASMAGORÍIS, DE RAMÓN GÓMEZ DE LA SERNA: ECOS DE BÉCQUER, MAUPASSANT Y POE
}

\author{
Rafael Cabañas Alamán \\ Saint Louis University, Madrid
}

\section{RESUMEN}

En este ensayo se estudia el horror fantástico y el tema del miedo en Los muertos, las muertas y otras fantasmagorías (1935) de manera que queda ejemplarizado cómo Ramón Gómez de la Serna hace uso literario de dichas emociones implícita y explícitamente, teniendo en cuenta las propias reflexiones del escritor sobre el horror y el miedo a la muerte. También se analiza cómo se representan dichas manifestaciones narrativas en algunas minificciones de este libro estableciéndose relevantes conexiones, relacionadas con los temas indicados, con algunas ficciones de Bécquer, Maupassant y Poe.

Palabras clave: miedo, horror, fantástico, muertos, muertas, Gómez de la Serna, Bécquer, Maupassant, Poe.

THE FANTASTIC HORROR AND FEAR

IN LOS MUERTOS, LAS MUERTAS Y OTRAS FANTASMAGORIAS,

BY RAMÓN GÓMEZ DE LA SERNA: ECHOES OF BÉCQUER, MAUPASSANT AND POE

\section{Abstract}

This essay will study the fantastical horror and the theme of fear in Los muertos, las muertas y otras fantasmagorías (1935) in order to exemplify how Ramón Gómez de la Serna makes literary use of such emotions implicitly and explicitly, taking into account the writer's own reflections on horror and fear of death. Analysis will be made of how these narrative manifestations are represented in some microstories included in this book, establishing relevant connections, related to the topics indicated, with some of Bécquer, Maupassant and Poe's fictions.

Keywords: fear, horror, the fantastic, the dead, Gómez de la Serna, Bécquer, Maupassant, Poe. 


\section{INTRODUCCIÓN}

Los muertos, las muertas y otras fantasmagorias (1935) es un libro compuesto por los dos apartados que le dan título al libro, a los que precede una «Lauda de entrada». "Lucubraciones de la muerte», subapartado incluido al comienzo de "Los muertos y las muertas», es el testimonio más extenso realizado sobre la muerte por Ramón Gómez de la Serna. López Molina escribe: «Ramón tuvo mucho de barroco y en ese mucho tiene cabida la muerte. Obsesionado por ella, recurrió al humor (a veces negro) para conjurarla» (2005: 17). Umbral considera a Gómez de la Serna "el escritor más optimista de nuestra literatura» (1978: 180), lo aleja de mantener una postura negativa de la muerte y presenta una visión un tanto ingenua ante dicho tema: «La muerte como acontecimiento cotidiano y la muerte como acontecimiento lírico son las dos ideas de la muerte que nos da Ramón» (1978: 182). Gregori considera el miedo una de las claves temáticas de la literatura del autor madrileño (2015: 469), y destaca que Los muertos, las muertas y otras fantasmagorías es un texto sobre la encarnación de la muerte y la pérdida de los rituales tradicionales que la rodean $(2015: 477)^{2}$.

Gómez de la Serna escribió sobre su aprensión a la muerte en reiteradas ocasiones, y este fenómeno aumentó en profundidad con la edad (Begońa 1980: 95). Pero el autor se refugia en el juego del arte del horror creando un humor macabro atemporal. Ya en una de las primeras reseñas aparecidas de Los muertos, las muertas y otras fantasmagorías se señala que en el libro aparecen «macabre anecdotes which carry one back to the Middle Ages» (Fucilla 1936: 174). El autor se hace servir de lo macabro para aliviar su propio temor. No olvidemos el título de su autobiografía, Automoribundia (1888-1948), donde se considera «humorista macabrero» (Gómez de la Serna 1948: 650). Según Núńez Florencio, «lo interesante de lo macabro es que da un paso más, hasta el punto de que se mueve en una órbita peculiar: lo macabro no tiene por qué ser lo tétrico o desagradable sin más, sino que puede buscar en la desgracia más atroz esa risa nerviosa o esa sonrisa que nos deja congelados» (2014: 52-53). Pero al mismo tiempo, hay que tener presente otro género literario afín, lo grotesco, una realidad heredada de Quevedo y Valle-Inclán y reflejada con la intención de hacer reír al lector. Comenta Roas de lo grotesco: «Su objetivo esencial, en su encarnación moderna, es revelar el absurdo y el horror de lo real provocando, a la vez, la sensación risueña del receptor» (2012: 26). El gran maestro de Gómez de la Serna de lo grotesco fue Quevedo, de quien escribe: "Quevedo es una carcajada en medio de los siglos, y eso es lo que le mantiene joven, temerario y terciado de capa en el proscenio de la vida» (Gómez de la Serna 1962a: 29) 3 . Arias, en su prólogo a Obras completas VII. Ramonismo V, de Ramón Gómez de la Serna, dedica

1 En lo sucesivo se citará de la edición de 1961, Madrid: Espasa Calpe, S.A.

2 Según David Roas, «el miedo es una condición necesaria para la creación de lo fantástico" (2011: 88).

3 Vid. «Quevedo y la muerte» en Quevedo, de Gómez de la Serna (1962a: 135-167). 
un apartado titulado «Ramonizar la muerte» (2001: 34-37) donde señala que «Los muertos y las muertas es uno de los textos a los que Ramón se dedica con particular mimo" (2001: 35). Dicho crítico refleja el carácter contradictorio del texto ante «el tira y afloja entre el lector de Séneca y Quevedo, y el Ramón optimista e iconoclasta» (2001: 38) y anima a estudiar en detalle las fuentes de los textos citados de los autores que aparecen en el libro, pero hasta la fecha nadie ha superado a Arias en dicha labor. Sirvan de ejemplo las fuentes señaladas por él del «Sueño de la muerte» de los Sueños de Quevedo y de ciertos textos de Gracián, Séneca y Calderón, entre otros $^{4}$. Murciano entabla claros vínculos entre el humor y la muerte en la poética de Gómez de la Serna: «Mas esta casi protesta de Ramón contra la muerte no encerraba amargura, ni desesperación, ni rebeldía. Como humorista de honda raíz, había adivinado el final del mundo» (1963: 298).

César Nicolás destaca «ese vitalismo de la muerte» (1984: 295) que se percibe en Los muertos, las muertas y otras fantasmagorías. De hecho, Ramón Gómez de la Serna desarrolló una teoría del «humorismo» en su ensayo "Gravedad e importancia del humorismo», cuyo apartado IV está precisamente dedicado al humorismo como modo de "pasar el trago de la muerte, y de paso para atravesar mejor el trago de la vida» (1930: 372), humor como terapia que se refleja para representar el horror fantástico en el libro que nos ocupa este estudio.

\section{2. "LOS MUERTOS Y LAS MUERTAS": REFLEXIONES PERSONALES}

En «Lucubraciones sobre la muerte» observamos una serie de comentarios que delatan el propio miedo, de manera que el discurso narrativo se despliega a modo de terapia autorreflexiva. Leemos: «La muerte es lo más corruptor que hay. Entra en las entrañas, en el honor, y lo deshace y perpetra la peor violación» (19). Sin

4 Vid. Arias (2001: 40-41). En el apartado «Notas a la edición» (1198-1200), de Obras completas VII. Ramonismo V, se muestran diferencias textuales entre las ediciones de Los muertos y las muertas y Arias arroja un dato revelador: "Invito al lector a leer o releer las prosas de Variaciones $A$ (tomo v de estas Obras completas, pp. 1185-1205), concretamente "El drama del cementerio de San Martín", "Meditaciones incongruentes sobre la muerte y los muertos", "Alrededor de los muertos", "las muertas" y "el viernes de los muertos", trasvases de crónicas de La Tribuna. En ellos le serán familiares ideas, incluso párrafos, que fueron adaptados o cosidos ya a la primera edición de Los muertos y las muertas, merced a ese relajado ejercicio de intertextualidad personal a que nos acostumbra el autor» (2001: 1200). Rivas trata el tema de la muerte en el capítulo de su tesis doctoral titulado "Constantes temáticas: la muerte» (2009: 196-208). Repite algunas de las fuentes señaladas por Arias y sigue la pista trazada por él, a quien no cita, pues alude a dichos textos mencionados de Gómez de la Serna relacionados con la muerte procedentes de Variaciones "A», parte de los cuales se encuentran en Los muertos, las muertas y otras fantasmagorias (1935).

5 Baglione escribe en el capítulo de su tesis doctoral titulado «Ramonismo, morte e oggetti»: «Exaltar la muerte, sin temor a evadirla, se convierte así en la posibilidad más auténtica de exaltar y fortalecer la vida misma, de celebrar su grandeza, precisamente a la luz de la muerte» (2019: 149). La traducción es mía. 
embargo, se pasa a trivializar con el concepto del miedo: «Es un susto que penetra en las galerías más oscuras del ser, que ciega su destino, que le hace dudar de su propia vida. Todo depende en la muerte del pánico mortal de los que siguen viviendo» (19, 20). Hallamos múltiples referencias lúdicas al miedo y al horror de manera recurrente. Se trivializa con el leitmotiv de la calavera: «Para consuelo de los hombres ha puesto Dios esa rasgada risa que queda en la calavera, pero los hombres son tan pedantes que no quieren admitir esa risa que de los que más se reirá será de ellos mismos, de los seriecistas, que lograron que fuese ajena a ellos su propia risa calaveral, pagando así el que no supieron encontrar su afinidad. Nadie ha visto jamás una calavera seria» (32).

La visión presentada de la muerte nos introduce en los rincones más espeluznantes de la calavera, quedando distorsionada la realidad que más horror genera: «Fijándose en ellas, se ve que tienen párpados de hueso en el fondo de sus órbitas, donde parecen haberse formado las telarañas últimas y quizá hay un agujerito suspensivo entre la vida y la muerte» (32-33). Percibimos imágenes vanguardistas que bordean lo siniestro ${ }^{6}$, a su vez, lo fantástico: «Calavera con todos sus dientes, jqué envidiable sería tener tu juventud y seguir viviendo! Poner a una calavera un libro encima y veréis cómo se transforma en un profesor mortuoris causa» (33). Estos testimonios a menudo adquieren carácter biográfico: «En mi adolescencia ya rodaban por el rastro madrileño calaveras verdaderas y calaveras de talla, sueltas, desprendidas de su retablo, y yo tenía una tremenda, mayor que de tamaño natural, con dientes como almenas, con buracos de conejera» (33).

El pavor que Gómez de la Serna sentía por la muerte se refleja con sus múltiples lucubraciones sobre el cráneo y la calavera envueltos en aires de horror fantástico, que quedan respaldadas lúdicamente con diversas menciones a Quevedo, maestro atemporal, y también a otros escritores: «Todos los cráneos serán reclamados y correrán hacia sus esqueletos como si llevasen dentro las víboras de los cuentos de Bécquer y Valle-Inclán. ¿Víboras y ratones? Quizá los segundos, porque yo he supuesto que en las órbitas o cuencas vacías de las calaveras se ocultan los ratones de la muerte» (34). La calavera es el objeto macabro por excelencia, y se define como tal: «Por eso esa obsesión del pintor y del imaginero ante esta imagen perfecta en su macabrez de la calavera, macabra pero noble, hecha por los picapedreros de la muerte, vaciada con finura de escultor supremo en material definitiva, como el signo más extraño» (35). Percibimos imágenes diabólicas que presentan la muerte como el monstruo aterrador, remontándonos al principio de los tiempos:

Según la leyenda, Satán, al ser arrojado del cielo, mientras descendía hacia la eterna noche del infierno, tenía la mirada vuelta hacia lo alto y fija en el ángel que le había denunciado, volviéndose más horrible su mirada a medida que se abismaba en las

${ }^{6}$ En «Espacios misteriosos, motivos fantásticos y terror absurdo en los microcuentos de Ramón Gómez de la Serna» se analizan aquellos relatos que sorprenden a causa de acontecimientos extraños, en los que las cosas aparecen como «asesinas», "asesinadas» o "devoradoras». (Vid. Cabañas Alamán 2012: 11). 
simas oscuras, y era una mirada tan agresora que el ángel denunciador empalideció tanto [...] que quedó convertido en el Ángel de la Muerte [...]. Todo viene, pues, de ese Ángel terrible y la Muerte se pasea por la historia Sagrada y por fin forma las aleluyas tragicómicas de la Danza Macabra (37).

Gómez de la Serna alude a la muerte, y la relaciona con personajes y escritores famosos haciendo uso del humor negro: «El suicidio de Larra es un rasgo de humorismo mudo» (48), y menciona que el humor está por encima de todo: «Los momentos de supremo humorismo han sido al borde de la tumba. No hay nada que los supere» (46). Apenas deja de aludir al miedo, con la siguiente excepción: «Lo único que no debemos temer es que nos dejen sin enterrar. Que no se apure nadie por esto. En el miedo de los demás está la inevitable expedición» (69).

En «Reflexiones de cementerio» se siguen exponiendo comentarios que dejan ver una obvia declaración del miedo expresada ante los horrores fantásticos que acechan ante la percepción de la muerte, creándose un aura lúdica: «El cementerio está lleno de monstruos, pero no se les ve» (105). Como bien señala Fernández-Medina, Gómez de la Serna siempre vivió con la preocupación de cómo presentarse a sí mismo en sus propios escritos (2014: 64), y en la narración que nos ocupa el escritor madrileño manifiesta su miedo como arma terapéutica en una narrativa autobiográfica que lo delata: «Gracias a esa constancia en la meditación, evitamos la tanatofobia, el miedo patológico a la muerte, que arredra al hombre» (106). En esta sección se sigue expresando un discurso en el que domina el humor negro macabro: «La calavera no escucha ya por los oídos, sino por la cuenca de los ojos, y no puede ser doctoral porque no puede retener las gafas" (107). Se recrea el cementerio con un hálito fantasmagórico paradójico, que nos remite a la existencia de los monstruos modernos por la aparente supresión de los mismos: «Los cementerios existen para darnos la gran lección y porque los seres de una época no pueden vivir entre los de otra: llegaría a serles irresistible la desmejora del tiempo, lo que de deshacedor tiene una época de las ilusiones de la otra. Por eso, no queda nadie de la época de los monstruos» (109). Pero si bien no aparecen los monstruos de antaño, los miedos se crean en un espacio donde prima el horror. El miedo a los cementerios queda expuesto explícitamente: «En los cementerios solitarios nos da miedo que nos maten y nos metan en un nicho o que -más misteriosamente- nos escamoteen» (121). Leemos juegos de palabras con cierto propósito humorístico: «Pero son tantos, son tantos los muertos, que ése es el consuelo de tontos; pero no si fuésemos completamente tontos, si no nos hiciésemos los tontos al pensar en la muerte, nos tendríamos que matar, nos moriríamos de miedo" (122). H.P. Lovecraft escribe: "La emoción más antigua y más fuerte de la humanidad es el miedo, y el miedo más antiguo y más fuerte es el miedo a lo desconocido» (2010: 27). El cementerio recoge «abombamientos que asustan» y la muerte es considerada como un monstruo per-

7 Remitimos al lector al relato El defensor del cementerio (1927), de Gómez de la Serna, que ha pasado desapercibido para la crítica, en el que don Amadeo lucha y fracasa en su empeńo para que no se destruya el cementerio en el que está enterrado su padre. 
sonificado: «Alguna vez hay perros en los cementerios y cuando ladran se siente un gran pánico, porque parece que harán salir a la muerte, señalando nuestra debida presencia en su coto cerrado" (124). También leemos greguerías relacionadas con el tema, como la siguiente: «Mucho sobrecogen los nichos llenos; pero más pánico dan los nichos vacíos, con su bostezo que mira hacia nosotros» (129). Entramos en un mundo en el que: «[t]odo es fantasía, menos la muerte» (130).

En la última sección de "Los muertos y las muertas», «Última hora», observamos una greguería que refleja el miedo de manera visual: "La muerte es como un rayo eléctrico que nos electrocuta sin electricidad» (137), pero el escritor se consuela a sí mismo dejándonos sorprendidos con una sincera reflexión: «¿Que tengo miedo a morir? ¿Y en qué cosa mejor voy a emplear el miedo?» (138). Y resulta evidente que sin ese doble sentir (horror y atracción a la muerte) no se hubieran podido narrar estas ingeniosas reflexiones, que anteceden a las minificciones de «Otras fantasmagorías» ${ }^{8}$.

\section{ECOS DE BÉCQUER, MAUPASSANT Y POE}

\subsection{LA MANO FANTÁSTICA}

Resulta interesante tener en cuenta la celebración del centenario del Romanticismo en 1935, justamente el año que coincide con la publicación de Los muertos, las muertas y otras fantasmagorías, y parece pertinente también señalar el interés de los románticos por los cementerios, como leemos en el siguiente artículo, titulado "Candor e ingenuidad de la escena fúnebre en la novela romántica»: «Con motivo de las visitas de arte a los cementerios románticos de Madrid, que como conmemoración del centenario del romanticismo español han organizado el Comité de Arte de los Estudiantes Católicos y "Los jóvenes y el arte" se ha insistido sobre la frecuencia con que en la literatura y en el arte de la época romántica se exalta el cementerio, la tumba y el monumento funerario» (Anónimo 1935: 90). En el prólogo de Gómez de la Serna a Cartas a las Golondrinas (1949) se hace un claro guiño a Bécquer: «Y como última advertencia prologal diré que si resultan sospechosos tantos recuerdos a Bécquer como posdata de todas mis cartas, hay que disculparme, porque dados una vez no podía dejarlos de dar siempre, pues me resultaba ingrato olvidarle como si así desacatase al hermano mayor en el más allá de las golondrinas» (1962b: 17).

8 Vela comenta sobre Rafael Romero Calvet (1884-1925), gran dibujante e ilustrador de arte macabro y de fantasía grotesca: «Una de las afinidades que debieron nutrir la relación amistosa de Ramón y Rafael hubo de ser sin duda su afición común por los cementerios y la atracción por la idea de la muerte, casi obsesiva en el caso del dibujante. Ambos comparten largas y provechosas caminatas por las sacramentales y camposantos de la capital, tal y como se evoca en Pombo: "¡Cuantos paseos por los cementerios para los que tenemos un pase de libre circulación!"» (2017: 38). Romero Calvet planeaba ilustrar Los muertos y las muertas, pero la relación con Gómez de la Serna se enfrió y el plan no llegó a materializarse. Remitimos al lector al capítulo «Ramón Gómez de la Serna. Pombo. Los muertos y las muertas» (Vela 2017: 29-46). 
Teniendo en cuenta la admiración que Gómez de la Serna sentía por Gustavo Adolfo Bécquer, es difícil pasar por alto los ecos literarios de «la mano» más famosa del escritor romántico. En «La mano»" se busca al asesino del doctor Alejo. Tras pasar un tiempo, acuden «despavoridas» la esposa y la criada a la policía, horrorizadas ante una mano que, con vida propia, se mueve por la casa. El narrador no parece sorprendido del modo en que lo hace el lector ante el hecho de que la mano sea autónoma. El juez, quien también viene a la casa, decide interrogarla y esta contesta con aura de misterio: «Soy la mano de Ramiro Ruiz, asesinado vilmente por el doctor en el hospital y destrozado con ensañamiento en la sala de disección» (167). La mano actúa como agente cosificado y animado que, inexplicablemente, provoca la muerte por venganza, de manera que el crimen queda resuelto en un mundo que no les resulta extraño a los personajes ${ }^{10}$.

En la leyenda "La promesa», de Bécquer, todo gira en torno al amor de Margarita, quien está enamorada de Pedro -el supuesto escudero favorito del conde de Gómara-, y queda desolada al saber que él debe irse a una batalla junto al célebre conde para luchar contra los árabes y conquistar Sevilla. El amante le había entregado un anillo, "símbolo de una promesa», como prueba de su amor. Ella accede y le pide que vaya a defender su honra de soldado, pero que regrese después a salvar la de ella. Margarita va con sus hermanos a despedir a los combatientes y se queda asombrada al ver que su amante no es un escudero, sino que es el mismo conde. Una vez en la guerra, este confiesa que estando en batalla en Sevilla, una mano le salvó milagrosamente la vida. La mano, blanca y hermosa, aparece y desaparece a los ojos del conde, le sigue y le causa «un profundo terror» (Bécquer 1954: 271). Un juglar confirma, al recitar el "Romance de la mano muerta», que cierta enamorada murió de pena y recrimina en su cantar que el amante no regresara, como había prometido. Margarita yace en su tumba, pero la mano, con el anillo de compromiso, no queda cubierta. El conde regresa a Gómara y se casa con Margarita donde está enterrada, y tras dicho suceso la mano, misteriosamente, «se hundió para siempre» (Bécquer 1954: 277).

En «La Main» (1883), de Maupassant, también hallamos a un juez, el sr. Bermutier, a su vez el narrador, y a varias mujeres horrorizadas por un crimen sucedido en París. Sin embargo, la historia se desvía a otra que narra el mismo juez dentro de la trama principal, para comparar con la extrañeza del crimen de París, suceso acontecido anteriormente que se convierte en el centro del relato. Siendo el sr. Bermutier juez de instrucción en Ajaccio, se encargaba de asuntos de vendetta (venganza). A modo de elevar el interés en el lector, leemos: «Allí encontramos los más hermosos temas de venganza que soñarse puedan» (Maupassant 1983: 32). El juez pasa a recordar el caso de un inglés, que había alquilado un chalecito en la zona, de

9 «La mano» fue publicada en la primera edición de Greguerías, en concreto en la sección 1. Intermedio «Caprichos» (Gómez de la Serna 1917: 45-46).

${ }_{10}$ Para el estudio del crimen en la narrativa larga de Gómez de la Serna ver Ramón y el arte de matar (El crimen en las novelas de Gómez de la Serna), de Serrano Asenjo (1992). 
quien se hablaba que había cometido «un crimen espantoso. Incluso se mencionaban circunstancias particularmente horribles» (33). El mismo juez propició conocer a sir John Rowell, quien se jactaba de sus cacerías e incluso de haber cazado a muchos hombres. Una vez en su casa, el narrador revela que observó un objeto negro: «Era una mano, una mano humana. No una mano de esqueleto, blanca y limpia, sino una mano negra reseca» (33). Y prosigue: "En torno a la muñeca, una enorme cadena de hierro, remachada, soldada a aquel sucio miembro, lo sujetaba a la pared con una argolla lo bastante fuerte como para atar a un elefante» (34). El inglés confiesa que se trata de la mano de quien fue su peor enemigo, a quien se la había cortado en América. El juez narra el temor que observa en sir Rowell, quien posee numerosas armas, y el narrador nos informa de que un año después el inglés «había muerto estrangulado». Tenía el cuello «perforado por cinco agujeros que se diría hechos con puntas de hierro» (34). El lector sabe, desde este momento, que la mano capturada tiempo atrás por sir Rowell ha acabado vengándose de él. La duda es ¿cómo pudo ser? El juez, quien sufrió escalofríos, observó que la mano había desaparecido, pero que uno de los dedos estaba en la boca del cadáver del inglés. El criado francés le comentó al juez que aquel había estado muy agitado quemando cartas que había recibido, cuyo contenido no queda revelado. A todo ello se le suma la pesadilla del juez: «Ahora bien una noche, tres meses después del crimen, tuve una espantosa pesadilla. Me pareció que veía la mano, la horrible mano, correr como un escorpión o como una araña a lo largo de mis cortinas y de mis paredes» (35). Al día siguiente de este suceso encontraron la mano en el cementerio, le faltaba un índice. Se trataba de un caso de venganza, según el juez, quien explica que el propietario de la mano no estaba muerto, que vino a buscarla con la otra que le quedaba. Sin embargo, las señoras no quedan satisfechas con la explicación.

Gómez de la Serna debió leer la narración de Maupassant, pues en su relato hallamos ecos literarios de «La Main». En ambas ficciones los asesinados mueren por estrangulamiento. También, el autor madrileño utiliza, como el francés, la metáfora de la mano como araña. En la minificción de Gómez de la Serna las mujeres encierran la mano, y la esposa del muerto, «llena de terror», va al juez, quien no tiene respuestas ante el extraño fenómeno (al contrario que sí las tiene el juez del cuento de Maupassant, aunque parece decepcionar a las señoras, ávidas de una explicación racional). La misma mano pasa a dar una explicación, de manera que el mundo extratextual, que es compartido con el lector, supera al de Maupassant en cuanto a que la mano de la ficción de Gómez de la Serna explica su propia venganza. Se soluciona así parcialmente el dilema del fenómeno extraño y se resuelve otorgándole voz a la mano, que se justifica a sí misma. El lector percibe una cotidianeidad normal de los personajes, que no quedan insatisfechos ante el acto de autoinculpación por la ejecución del crimen en un escenario fantástico.

En las tres ficciones comentadas, la imagen en cuestión horroriza (en «La Main» y en "La mano») o cautiva (en "La promesa») a los personajes, y son estas manos, en los tres relatos, las que se toman «la justicia por su mano» (valga la redundancia), pero en el de Gómez de la Serna, como en «La promesa», se le da el suficiente poder a dicho leitmotiv para hacer justicia y satisfacer así a los personajes y a los lectores: el conde de Gómara se casa con Margarita, la familia de ella no queda 
deshonrada y las señoras y el juez en la minificción de Gómez de la Serna quedan satisfechos ante la resolución del asesinato. La mano es "la cosa» que manipula el entorno, pasa a tomar decisiones y a ejercer el acto de venganza ${ }^{11}$.

\subsection{El HORROR AL PROPIO DOBLE}

En «El estatuado» Cabeza de Sabio asiste a la inauguración de su propia estatua. "Estatuado», literalmente, significa "decorado con estatuas», y aunque no se suele usar dicho término como aparece en el título de la minificción, al narrador le sirve para el propósito planteado: narrar algo irreal desde el punto de vista convencional. Resulta atípico que la estatua se erija estando vivo el protagonista, quien teme a su propia imagen "estatuada», como si lo estuviera invadiendo, de manera que llega a percibir sensaciones de ella misma. Se juega con el malestar físico, con los «insomnios» que invaden al personaje y le sobresaltan, con los «temblores de frío" y se superponen imágenes fantásticas que nos hacen dudar si el personaje está reviviendo, pensando o soñando absurdamente que él mismo es una estatua, cuya obsesión lo tiene trastornado: "Cabeza de Sabio" tenía temblores de frío, agarrado a su piedra, y sentía que las hojas secas del parque en que estaba estatuizado le daban bofetones de otoño» (176). Siente gran malestar, como por estar dentro de ella, y tristeza por haber perdido la libertad. Se enferma con la presencia de su doble, una estatua que le recuerda a la muerte que aún no le ha llegado, y lo que debería llenarle de orgullo, tener su propia estatua (figura homenaje al sabio), se proyecta como sombra de su futuro cadáver.

El narrador plasma un doble juego con la realidad que horroriza al personaje e incide en los síntomas que padece. Pero nos preguntamos ¿quién los sufre, el personaje, la estatua de sí mismo que le horroriza, o se trata de la unión entre ambos que surge del alucinamiento?: “Cabeza de sabio" sentía reuma de fuente pública y pedradas de agua fría, sintiéndose manoseado y lejano en cementerio de vivos» (177). El narrador juega con las palabras, expresando lo indecible de manera metafórica ${ }^{12}$. Finalmente el estatuado no soporta su propia imagen de piedra, que le transmite frío" y «escalofríos», y acaba destruyéndola, pues la percibe como enemiga: «La estatua tenía la culpa de sus neuralgias pertinaces» (177).

$\mathrm{Al}$ igual que muchos personajes consagrados adoptan determinadas medidas para intentar destruir la imagen preconcebida que se crea de ellos, el estatuado se encarga de destruir su propia estatua. Esto significa una prueba del claro rechazo dirigido a su alter ego, conducta común en la literatura del horror (Carroll 2004: 46). Pero también surge la duda de si se trata de un sueño o de si realmente hay, a modo

11 Vid. el análisis de Senos de Gregori, donde aparecen ejemplos de mutilación y de "gynophagia fantasies» (2015: 473).

${ }^{12}$ Bellemin-Noël (1971) alude reiteradamente a la retórica de lo indecible en la literatura fantástica. 
de realidad fantástica, un intercambio que suscita sensaciones compartidas entre el sabio y la estatua, que en la realidad de la ficción le erigieron estando vivo y que a él le angustia, horroriza y enferma ${ }^{13}$. Aunque se exagera de manera paródica, contrarrestándole importancia a la imagen de la falsa eternidad y a la relevancia que se le da a la idea de inmortalizar a las personas aparentemente importantes ${ }^{14}$, el miedo a la proyección de la propia sombra queda patente.

No podemos pasar por alto la leyenda de Bécquer «El beso»" ${ }^{15}$. Aquí, la imagen de la estatua de dońa Elvira obsesiona a un soldado francés y no termina con un final feliz para él. Gómez de la Serna, en cierta manera, le da un giro a la historia del escritor romántico. Si bien el amante (estatua) de doña Elvira golpea violentamente al soldado, en "El estatuado» el hombre destruye a la estatua, que queda totalmente desmitificada por lo que representa.

En «El estatuado» se hace uso del juego del doble, como sucede en el caso de tantos escritores que tratan el horror fantástico. El cuento es un buen ejemplo de Doppelgänger paródico (teniendo en cuenta que Doppelgänger es el vocablo alemán para definir el doble fantasmagórico) ${ }^{16} \mathrm{y}$ en parte resulta un planteamiento absurdo de imágenes superpuestas. De nuevo percibimos ecos de Maupassant, en este caso pensamos en "El Horla» (1886) ${ }^{17}$, donde el protagonista está tan obsesionado con el ser que lo acosa que vive para intentar destruirlo, lo que no llega a conseguir ${ }^{18}$. El misterio del propio doble, que se releva al final, es lo que enriquece la ficción, cuando el personaje se descubre a sí mismo visto de espaldas.

A diferencia de las ficciones señaladas de Maupassant y Béquer, Gómez de la Serna consigue que su personaje domine finalmente y venza a la figura de su doble para poder así tal vez mitigar el miedo a la muerte física, representada por la estatua. Pero también podría argumentarse que el estatuado desea rehuir de la falsa sombra que proyecta, a los ojos de los demás, y de la infame inmortalidad personalizada por su doble, que no parece interesarle y del que se avergüenza. La imagen de la

${ }^{13}$ Herrero trata el tema de la enfermedad en algunas narraciones de Gómez de la Serna publicadas entre 1914 y 1934. Resulta especialmente interesante el apartado «Enfermedad y muerte», en el que Herrero estudia ciertas novelas largas del autor madrileño (2001: 201-202).

${ }_{14}$ Recordemos la actitud contraria de Gómez de la Serna a ser miembro de la Real Academia Española, como leemos en «Las palabras y lo indecible» (1936: 57) y en Nuevas páginas de mi vida (1970: 137).

15 Vid. Bécquer (1954: 302-319).

16 Martín López estudia el Doppelgänger paródico en varias obras literarias (2006: 69-73).

17 En «El Horla» el protagonista siente una presencia extraña, algo que denomina como «el Horla». Estamos ante una narración en primera persona, como un tipo de relato alucinatorio. Todo comienza cuando desde su casa observa un barco que navega por el río, con un saludo, el narrador abre camino de un horrible proceso. Su mente queda invadida por pesadillas y síntomas angustiosos. El narrador considera el misterio de lo invisible, la teoría de que si hubiera otros sentidos uno podría descubrir muchas más cosas sobre la realidad. Al final decide suicidarse. (Vid. Maupassant, 1983: 51-64).

${ }^{18}$ En «William Wilson» (1839), de Poe, el protagonista cuenta su historia, que da comienzo desde niño, cuando estudiaba en un colegio religioso. Aunque el «malo» destruye al «bueno», su doble, le espera un terrible final. (Vid. Poe 1982: 626-641). 
estatua es un símbolo clásico que fue retomado por los poetas modernistas (Kovarskaya: 2011), y dicha imagen es introducida en lo cotidiano de manera que se le da un giro radical a la percepción de la misma ofreciendo una insólita visión vanguardista. Esta vez «la cosa» es repudiada, hecho que no deja de ser humorístico. Leemos:

Mi humorismo es un humorismo que descansa sobre las cosas que convierte a las personas en cosas, humorismo en que me he refugiado al ver que los seres son máquinas de ambición y traición y las cosas son lo único bueno de la vida, siempre verdaderas santidades, dependiendo quizá de eso el que cuando un santo es escultorizado, es decir, convertido en cosa de piedra, su santidad, se hace convincente (Gómez de la Serna 1948: 651).

Si bien estamos ante el escritor "protector de las cosas", se crea un personaje que destruye su estatua como revés inesperado e irónico que contrasta en una historia que conduce a un sorpresivo e ingenioso final.

\subsection{Las máscaras y Poe}

Según Gómez de la Serna: «Poe como Charlot realiza lo cómico muy serio, elevando la categoría de la comicidad, sin sonreír, desenvolviendo lo grotesco como una gran teoría dramática» (1953: 17) ${ }^{19}$. En «La sorpresa del baile» encontramos una sutil referencia a «La máscara de la Muerte Roja» (1842), de Poe ${ }^{20}$ : «Las sorpresas de los bailes de máscaras son inverosímiles, y un día apareció enmascarada dońa muerte [...]» (143). En dicho relato una misteriosa peste ataca la ciudad de Próspero, príncipe de una ficticia nación, al cual le complace otorgarse todo tipo de placeres. Tras darse cuenta de que la peste ataca a toda su región, decide encerrarse en su castillo, junto con varios cientos de nobles de su corte que intentan escapar de la Muerte Roja. Cierta noche, el rey decide realizar la mejor fiesta de disfraces jamás hecha. Durante el transcurso de la fiesta Próspero se fija en un extraño disfrazado con un atuendo negro y el rostro cubierto por una máscara que representa una víctima de la peste. El príncipe, que se siente gravemente insultado por ello, le requiere al desconocido que se identifique. Para horror de todos, el invitado no sólo se revela como víctima de la enfermedad, sino como la personificación de la misma Muerte. A partir de ese momento, todos los ocupantes del castillo contraen la enfermedad

19 En «Poe Ramonizado» Hoddie resalta la visión literaria de Gómez de la Serna de Poe y compara a los dos escritores según opiniones del autor madrileño reflejadas en la biografía que este escribió del «héroe americano» (1999: 169-214).

${ }^{20}$ Rivas conecta «La sorpresa del baile» con «Hop-Frog», de Poe, que trata de la historia de la venganza espeluznante de un bufón enano sobre un rey y sus siete ministros (2008: 308309). Las conexiones con Poe las vuelve a tratar Rivas en el capítulo de su tesis titulado «Fuentes, Goya y Poe» (2009: 143-151), donde analiza la misma minificción y establece conexiones con otra de Gómez de la Serna, «El mono regicida», de Variaciones "A» [1925], en la que el mismo narrador alude a Poe y a «Hop-Frog». 
y mueren ${ }^{21}$. ¿Es este un augurio para «La sorpresa del baile»? En esta minificción estamos ante un baile de máscaras en el que el narrador nos pone en situación: «La rubia osada de los claveles rojos en el pelo, blanca y sangrante, había gritado con gritos de horror en el palco cerrado» (143). Ella descubrió que su pareja era, en sus palabras, «un mono horrible», del que no había notado nada extraño hasta que él le relevó la verdad en el antepalco. Todos en el baile se quedan inquietos, y la policía les hace quitarse los antifaces para encontrar al mono disfrazado de dominó, ante la duda de todos de si el mono se había convertido en hombre o de si había desaparecido. Se crea un contexto fantástico en el que surge el «mono horrible» que provoca «horror» en la mujer. Pensamos en la referencia y pista inicial de «La máscara de la Muerte Roja» y prevemos un fatal desenlace para los presentes en el baile. La policía indaga y le pregunta a la protagonista: «-¿Pero no notó usted alguna señal particular en él? [...]. - Hay tantos banqueros con una figura igual... Era galante, obsequioso y nunca brazo humano ciñó mi cintura como el suyo [...]» (143). Al final no sabemos si el mono ha vuelto a convertirse en hombre o si se ha marchado: «La policía y los organizadores hicieron caer todos los antifaces buscando al mono disfrazado, pero el dominó azul había desaparecido y el baile quedó lleno de inquietud ante esa suposición del mono convertido en hombre mundano y galante» (143). La referencia paródica al hombre «mono» (o mono hombre) queda ahí, pero también la crítica parece señalar a cierto prototipo de personaje pudiente, pues se considera la posibilidad de que el mono sea un banquero.

\section{EL ESPACIO DEL MAR Y LOS SUEÑOS}

En «El buzo loco» se recrea un viaje fantástico en un espacio donde hay «propinas muertas», "cánceres escapados a la ocultación» y «desangrados pasajeros» que son presenciados por el ojo inmenso del buzo. El momento más estremecedor que causa un horror fantástico es cuando el buzo abrió la puerta del comedor y los muertos «se levantaron de sus asientos y se movieron en zarabanda de peces humanos, en brujería de corro de prendas, como si se hubiese dado música y movimiento a unos muñecos» (141-142), lo que espanta al buzo y sale «corriendo por los pasillos». Se desafían, así, las leyes de la física. Dudamos dónde está y cómo puede correr cuando está bajo el agua, pero lo que averiguamos es que los efectos de lo que presenció lo vuelven loco: "Cuando le quitaron el aparato de ludión que le empeceraba la cabeza, prorrumpió en las carcajadas y los estornudos de la locura» (142). De nuevo se aborda lo indecible y la incongruencia, típica expresión narrativa de Gómez de la Serna, que se fusiona con el horror y el humor, punto relevante al pensamiento de Carroll: "The incongruity theory of humor, of course, is especially suggestive in terms of our questions about the relation of horror and humor» (1999: 154).

${ }^{21}$ Vid. Poe (1982: 269-273). 
En la minificción «En un baile de los sueños» surge un ambiente fantasmagórico. El horror invade a la protagonista, y desde el primer momento presenciamos el sueño físico, por cansancio, de Mara, que nos hace pensar en el doble significado de «sueño». El narrador nos explica que «Mara se metió en aquel sueño doblegada por el cansancio», por lo que ella se adentra en otro sueño y experimenta miedo al encontrase en un baile donde todas las asistentes iban igualmente vestidas de dominó verde y con el mismo antifaz. Mara teme que Luis, su acompañante, la confunda con las otras mujeres. De repente, Mara también aparece vestida de la misma manera con un antifaz, y se narra lo que siente: «Entonces comenzó el sudor amarillo del sueño, la insolución del caso, el pánico ensañado de los sueños» (186). Aun sabiendo que se trata de un relato con claro tono de parodia de un cuento de hadas, el narrador nos hace partícipes de las sensaciones físicas de Mara debido al temor y agobio que le invade. El juego con el término «miedo» es doble: Mara lo siente al ser una más entre todas, y se afirma que los sueños, en sí, lo provocan, lo que no es necesariamente una afirmación errónea ni exagerada. Se concluye con un final parcialmente feliz para Mara, quien se siente aliviada porque es la única persona que finalmente presenta la cara descubierta, por lo que Luis pudo reconocerla y no confundirla ni perderla entre todas. Se despierta contenta, pero no podemos pasar por alto que se siente "deshonrada ante tantas máscaras con el rostro tapado» (186). Parece quedar expuesta la idea de la deshonra que implica el ser uno mismo, ante los ojos de los demás, en un determinado ambiente social.

\section{CONCLUSIÓN}

En Los muertos, las muertas y otras fantasmagorías (1935), el miedo y el horror fantástico queda ejemplarizado teniendo en cuenta las propias reflexiones de Gómez de la Serna ante la muerte. En "Los muertos y las muertas": Reflexiones personales», el autor despliega un discurso narrativo en el que se vivifica la muerte, y lo hace conjugando profundidad de pensamiento e ironía, con el fin de deconstruir tradiciones, mitos, fábulas, fantasmagorías populares y géneros literarios que en distintos periodos históricos han representado el horror a la muerte. En algunas minificciones de «Otras fantasmagorías» nos introducimos en un mundo de realidades fantásticas, comparable al que hallamos en ficciones de Bécquer, Maupassant y Poe, en relación con los temas estudiados, y con gran ironía el autor se distancia del miedo de los personajes de su propia creación, como sucede en «El buzo loco» y en «En un baile de los sueños».

En «Las palabras y lo indecible» Gómez de la Serna expresa su propio «horror al vacío»: "El vacío nos ha rodeado en nuestra época y casi todos nuestros actos y nuestras invenciones son una rebeldía del horror al vacío, una reacción contra ese horror, nerviosos, alterados y frenéticos de dislates» (1936: 63). En el texto estudiado se utiliza el miedo como leitmotiv y "condición necesaria» que oscila entre lo paródico y lo serio, teniendo en cuenta el humor que surge en ciertas escenas narrativas cuya representación le sirve al autor como propio ejercicio de escriptoterapia ante el temor a la muerte que le acompañó durante toda su vida, como leemos tam- 
bién en Cartas a mí mismo ${ }^{22}$, publicadas muchos años después, en las que trasluce ese miedo al vacío de la muerte. En una carta leemos: «Ni tú ni yo podemos darnos el pésame el día de nuestra muerte y este vacío imposible de ser llenado da cierta melancolía a nuestra correspondencia» (Gómez de la Serna 1956: 125). No obstante, en Los muertos, las muertas y otras fantasmagorías se percibe parcialmente una «emoción positiva» (Bantinaki 2012: 383) ${ }^{23}$ que en ocasiones conecta con lo macabro ${ }^{24}$, dentro de un contexto literario en el que destaca la fantasía ${ }^{25}$, de manera que queda elaborada una particular visión del miedo y del horror fantástico que se proyecta en uno de los textos más sorprendentes e ingeniosos de Ramón Gómez de la Serna.

ReCiBido: enero de 2020; ACEPTADo: abril de 2020

22 Según Riordan, «writing intimately about traumas or other stressors has positive physical and psychological benefits» (1996: 266). Gómez de la Serna escribió Cartas a mí mismo, publicadas en conjunto en 1956. «La escritura de estas "cartas a sí mismo" le sirve de terapia a Ramón, revelan la obsesión por la muerte y claros testimonios de su soledad» (Cabañas Alamán 2011: 153).

${ }^{23}$ Opina Bantinaki: «I argue that fear in response to horror can be experienced as an overall positive emotion, that is, an emotion toward which the subject has a positive stance and thus enjoys experiencing, leaving it open whether the emotional experience is also affectively pleasurable or affectively painful» (2012: 383).

${ }^{24}$ Lo macabro surge del miedo, pero hay que luchar contra él: «Lo macabro puede suponer una actitud pesimista, pero lo que está claro es que no se queda en el simple lamento» (Núñez Florencio 2014: 53).

${ }^{25}$ Hernández comenta: «[E]lementos como la intertextualidad, la fantasía o el humorismo, presentes en el conjunto de la obra ramoniana, tuvieron una especial conexión con el cultivo de sus microrrelatos» (2012: 199). 


\section{BIBLIOGRAFÍA}

Anónimo (6 de enero 1935): "Candor e ingenuidad de la escena fúnebre en la novela romántica», Blanco y Negro, 90.

Arias, Alfredo (2001): «Prólogo», en Ioana Zlotescu (ed.), Ramón Gómez de la Serna, Obras completas VII, Ramonismo v. Caprichos, Gollerias, Trampantojos (1923-1956), Barcelona: Círculo de Lectores, Galaxia Gutenberg, 1-58.

BAgLIONE, Andrea (2019): RAMÓN e l'umorismo, tesis doctoral inédita, dir. Marco Succio, Génova: Università degli Studi di Genova.

Bantinaki, Katerina (2012): «The Paradox of Horror: Fear as positive emotion», The Journal of Aesthetics and Art Criticism 70 (4) Fall: 383-392.

BÉCQuer, Gustavo Adolfo (1954): Obras completas, Madrid: Aguilar.

Begoña, José (1980): «Evaluación y contraste dentro de una de las constantes de Ramón Gómez de la Serna», en Evelyn Rugg y Alan M. Gordon_(coords.), Actas del Sexto Congreso Internacional de Hispanistas, Toronto: Universidad de Toronto, 94-98.

Bellemin-NoËL, Jean (1971): «Des formes fantastiques aux thèmes fantasmatiques», Littérature 2: 103-118.

Cabañas Alamán, Rafael (2011): «El recurso auto-epistolar como terapia: motivos temáticos recurrentes y greguerías en Cartas a mí mismo (1956), de Ramón Gómez de la Serna», Olivar. Revista de Literatura y Cultura Españolas 12 (16): 137-157.

Cabañas Alamán, Rafael (2012): «Espacios misteriosos, motivos fantásticos y terror absurdo en los microcuentos de Ramón Gómez de la Serna", LEJANA. Revista Crítica de Narrativa Breve 4: 1-13.

Carroll, Noël (1999): «Horror and Humor», The Journal of Aesthetics and Art Criticism 57 (2) Spring: 145-160.

Carroll, Noël (2004) [1990]: The Philosophy of Horror or Paradoxes of the Heart, Abingdon: Taylor $\&$ Francis.

Fernández-Medina, Nicolás (2014): «Autobiography and the Task of the Writer: The Case of the Young Ramón Gómez de la Serna», Anales de la literatura española contemporánea 39 (1): 61-83.

Fucilla, Joseph G. (1936): Reseña de Los muertos, las muertas y otras fantasmagorías, de Ramón Gómez de la Serna, Books Abroad 10 (2) Spring: 174.

Gómez de la Serna, Ramón (1917): Greguerias, Valencia: Prometeo.

Gómez de la Serna, Ramón (1927): El defensor del cementerio, en Revista de Occidente 60 julioseptiembre, 317-338.

Gómez de la Serna, Ramón (1930): "Gravedad e importancia del humorismo», Revista de Occidente 28: 348-391.

Gómez de LA SERna, Ramón (1961) [1935]: Los muertos, las muertas y otras fantasmagorias, Madrid: Espasa Calpe, S.A.

Gómez de la Serna, Ramón (1936): «Las palabras y lo indecible», Revista de Occidente 60 (151): 56-87.

Gómez de la Serna, Ramón (1948): Automoribundia (1888-1948), Buenos Aires: Editorial Sudamericana. 
Gómez de la Serna, Ramón (1953): Edgar Poe. Elgenio de América, Buenos Aires: Editorial Losada, S.A.

Gómez de la Serna, Ramón (1962a) [1953]: Quevedo, Madrid: Espasa-Calpe, S.A.

Gómez de la Serna, Ramón (1956): Cartas a mi mismo, Barcelona: Editorial AHR.

Gómez de la Serna, Ramón (1970) [1957]: Nuevas páginas de mi vida, Madrid: Alianza editorial.

Gómez de la Serna, Ramón (1962b): Cartas a las golondrinas, Cartas a mi mismo, Madrid: Espasa Calpe, S.A.

Gregori, Eduardo (2015): «Embodying the Spanish Avant-Garde: Disability and Gender in Ramón Gómez de la Serna», Hispanic Review 83 (4): 467-483.

Hernández Hernández, Darío (2012): El microrrelato en la literatura española. Origenes históricos: modernismo y vanguardia, tesis doctoral inédita, dir. Nilo Francisco Palenzuela Borges, Tenerife: Universidad de La Laguna.

Herrero, Carmen (2001): «El concepto de enfermedad en las novelas de Ramón Gómez de la Serna (1914 1934)», Siglo Diecinueve (Literatura hispánica) 7: 197-208.

Hoddie, James H (1999): El contraste en la obra de Ramón Gómez de la Serna, Madrid: Editorial Pliegos.

Kovarskaya, Yulia (2011): «La hermenéutica literaria de la estatua en el modernismo poético ruso y espańol: Cernuda y Briusov», Mundo Eslavo 10: 67-72.

López Molina, Luis (2005): «Introducción», en Luis López Molina (ed.), Ramón Gómez de la Serna, Disparates y otros caprichos, Palencia: Menoscuarto, 7-38.

Lovecraft, H.P. (2010): Juan Antonio Molina Foix (ed.), El horror sobrenatural en la literatura y otros escritos teóricos y autobiográficos, Madrid: Valdemar.

Martín López, Rebeca (2006): Las manifestaciones del doble en la narrativa breve española Contemporánea, tesis doctoral inédita, dir. Fernando Valls, Barcelona: Universidad Autónoma de Barcelona.

Maupassant, Guy de (1983): Cuentos pavorosos, Esther Benítez (trad.), Barcelona: Ediciones Forum.

Murciano, Carlos (1963): «La muerte, esa greguería», Cuadernos Hispanoamericanos 158: 297-299.

Nicolás, César (1984): «Lo fantástico nuevo en Ramón Gómez de la Serna», Anuario de Estudios Filológicos 7: 281-297.

NúŃEz Florencio, Rafael (2014): «La muerte y lo macabro en la cultura española», Dendra Médica. Revista de Humanidades 13 (1): 49-66.

Poe, Edgar Allan (1982): The Complete Tales and Poems of Edgar Allan Poe, Inglaterra, Nueva York, Australia, Canadá: Penguin Books Ltd.

RIORDAN, Richard J. (1996): «Scriptotherapy: Therapeutic Writing as a Counseling Adjunct», Journal of Counseling \& Development 74 (3) enero-febrero: 263-69.

Rivas, Antonio (2008): "La poética del absurdo en los "caprichos" de Ramón Gómez de la Serna", en Irene Andrés Suárez y Antonio Rivas (eds.), La era de la brevedad. El microrrelato hispánico. Actas del IV Congreso Internacional de Minificción, Universidad de Neuchâtel (Neuchâtel, 6-8 noviembre de 2006), Palencia: Menoscuarto, 301-315.

Rivas, Antonio (2009): La narrativa breve de Ramón Gómez de la Serna, tesis doctoral inédita, dir. Irene Andrés Suárez, Neuchâtel: Universidad de Neuchâtel.

Roas, David (2011): Tras los limites de lo Real. Una definición de lo fantástico, Madrid: Páginas de espuma. 
RoAs, David (2012): «El cuerpo grotesco en el siglo xIx: Entre el horror y la risa», Vitória Da Conquista 1 (2): 24-32.

Serrano Asenjo, José Enrique (1992): Ramón y el arte de matar (El crimen en las novelas de Gómez de la Serna), Granada: Caja General de Ahorros.

Umbral, Francisco (1978): Ramón y las vanguardias, Madrid: Espasa-Calpe, S.A.

Vela, David (2017): Rafael Romero Calvet. Ilustraciones y cuentos de locura y muerte (autoedición: https://www.amazon.es/dp/8469765833). 
